JOURNAL OF PERIODONTAL RESEARCH doi:10.1111/j.1600-0765.2012.01510.x

\title{
Early and late studies of EMD use in periodontal intrabony defects
}

\author{
Mueller VT, Welch K, Bratu DC, Wang H-L. Early and late studies of EMD use in \\ periodontal intrabony defects. J Periodont Res 2013; 48: 117-125. ( 2012 John \\ Wiley \& Sons $A / S$
}

Background and Objective: The clinical efficacy of EMDs for the treatment of periodontal infrabony defects has been reported. However, recent publications have questioned the validity of results from early findings. Hence, the purpose of this study was to compare the results obtained from early and late studies when EMD was used as an adjunct in treating human intrabony defects during flap surgery. The aim of this meta-analysis was to evaluate the validity of results published from early studies compared with those published from later studies.

Material and Methods: PubMed and MEDLINE searches were performed. The evaluation period was 1997-2010 and it was divided into two groups of equal periods of time: early studies (1997-2003) and late studies (2004-2010). The clinical parameters assessed were clinical attachment level (CAL), probing pocket depth and bone gain (BG; measured as a percentage or in $\mathrm{mm}$ ).

Results: No statistically significant difference was found between the results obtained from early studies (1997-2003) and late studies (2004-2010) with regards to CAL gain, probing pocket depth reduction and BG. Nonetheless, both study periods showed a benefit for using EMD to treat periodontal infrabony defects when compared with the groups without EMD during open flap surgery.

Conclusions: The results obtained from this study failed to show any potential differences between the results published from early studies and late studies with regards to the clinical effectiveness of EMD in treating periodontal infrabony defects.

\section{T. Mueller ${ }^{1}$, K. Welch ${ }^{2}$, D. C. Bratu ${ }^{3}, \mathrm{H}-\mathrm{L}$. Wang ${ }^{4}$}

${ }^{1}$ Resident, Graduate Periodontics, School of Dentistry, University of Michigan, Ann Arbor, MI, USA, ${ }^{2}$ Statistical Consultant, Center for Statistical Consultation and Research, University of Michigan, Ann Arbor, MI, USA, ${ }^{3}$ Assistant Lecturer, University of Medicine and Pharmacy "Victor Babes" Timisoara Faculty of Dentistry, Department Of Pedodontics \& Orthodonticsm Timisoara, Timisoara, Romania and ${ }^{4}$ Professor and Director of Graduate Periodontics, Department of Periodontics \& Oral Medicine, School of Dentistry, University of Michigan, Ann Arbor, MI, USA

Hom-Lay Wang, DDS, MSD, PhD, Professor and Director of Graduate Periodontics, Department of Periodontics and Oral Medicine, University of Michigan, School of Dentistry, $1101 \mathrm{~N}$. University, Ann Arbor, MI 48109-1078, USA Tel: +7347633383

Fax: +7349360374

e-mail: homlay@umich.edu

One Sentence Summary: Additional application of enamel matrix derivatives was shown to be more effective in managing periodontal intrabony defects when compared to traditional flap surgery regardless when the papers were published.

Key words: biological agents; Emdogain; enamel matrix derivatives; periodontal infrabony defects

Accepted for publication June 8, 2012
The ultimate goal of periodontal therapy has always been the regeneration of the lost periodontal supporting structures. Several methods have been employed over time to achieve this goal. Guided tissue regeneration (GTR) using bone grafts, barrier membranes or a combination of both has been the most commonly used approach. The results obtained from these treatments have been shown to be superior to open flap debridement (1-4). However, GTR has been proven to be very technique sensitive and the results achieved were often unpredictable (4). This can be attributed by frequent exposure (4) of the implanted materials to the oral cavity and many other factors such as interproximal bone level, defect morphology, wound control, smoking habit and poor oral hygiene (5-10). Consequently, a search began for second-generation regenerative agents. Among these agents, EMDs have become the first bioactive agent to be used in periodontal clinical practice. The commercially available product is called Emdogain (Strauman international, Basel, Switzerland). EMD is obtained from developing teeth germs of 6-mo-old piglets (11) and is believed to participate in the development of periodontal supporting structures during tooth-formation processes (12) such as amelogenesis (13). Furthermore, EMD can also exert effects on cell attachment, spreading, chemotaxis, proliferation and cell survival (14). Moreover, EMD has the 
capacity to express growth factors, cytokines and extracellular matrix components, as well as molecules pertinent to osteogenesis and osteoclastogenesis (14). Lastly, EMD possesses antibacterial function which is largely attributed to its vehicle, propylene glycol alginate $(14,15)$. EMD has also been shown to enhance periodontal regeneration after surgery (11), to improve treatment results in intrabony and mandibular Class II furcation defects (2), to minimize postsurgical complications when used as an alternative to GTR barrier membrane (16) and to aid soft tissue root-coverage procedures (17).

Generally, studies published around the time that a product is launched often report favorable clinical outcomes (18-20). However, a recent publication documented inferior results of EMD in noncontained defects when compared with GTR (21). Hence, the aim of this meta-analysis was to determine any differences between the results of early studies and late studies results when EMD was used as an adjunct to treat human intrabony defects during flap surgery.

\section{Material and methods}

PubMed and MEDLINE searches were performed for the period January 1997 to July 2010. Articles included were clinical trials in which EMD was used for the treatment of intrabony defects. The search used the medical subject heading (MeSH) terms Emdogain, enamel matrix derivatives, enamel matrix proteins, dental enamel proteins, periodontal intrabony defects and biologic agents. Inclusion criteria included English language publications of human clinical trials (randomized clinical trials, case-control studies and case series). Clinical outcomes such as clinical attachment level (CAL) gains, probing pocket depth reductions and bone gain (BG) were documented. Studies were then divided into two evaluation time-periods: 1997-2003 and 2004-2010. Moreover, studies limited to the use of EMD alone or in which at least one arm of the study evaluated EMD alone for regeneration of intrabony defects were included in this meta-analysis. Furthermore, each evaluation period was divided according to the available outcome measures: probing pocket depth reduction (in $\mathrm{mm}$ ), CAL gain (in $\mathrm{mm}$ ) and BG (in $\mathrm{mm}$, or as a percentage if available). Lastly, the standard deviation of each individual parameter had to be reported, in order to facilitate statistical analysis. In total, 76 studies were screened and, of these, 39 met the inclusion criteria. Studies were excluded if they did not report the clinical parameters listed above, if no standard deviations were present, if no full-text reports were retrievable or if no treatment with EMD alone was evaluated.

Twenty early studies (carried out in the time-period from 1997 to 2003) met the inclusion criteria (18-20,22-38). A total of 11 studies reported BG after treatment with EMD: four reported BG in both $\mathrm{mm}$ and as a percentage $(14,18,19,24,37)$; five studies reported BG in mm $(22,27,28,31,36)$; and only two reported $\mathrm{BG}$ as a percentage $(25,26)$. Eighteen late studies (carried out in the time-period 2004-2010) met the inclusion criteria $(16,21,27,39-53)$. A total of nine studies evaluated BG: three reported $\mathrm{BG}$ in both $\mathrm{mm}$ and as a percentage (41-43,53); five reported BG in mm only $(44,46,50,52,53)$; and one study reported bone gain only as a percentage (48) (Tables 1A,B).

The statistical analysis was performed by the Center for Statistical Consultation and Research at the University of Michigan. We used a random-effects meta-analysis to combine information from the 39 studies included in this meta-analysis, stratified by group (early studies vs. late studies). A random-effects metaregression was used to compare the effect of each outcome variable for early studies vs. late studies. All statistical analyses were carried out using STATA SE version $11.2 \phi$ (StataCorp LP, 4905 Lakeway Drive, College Station, TX 77845, USA).

\section{Results}

A total of 39 studies were available, 20 in the early time-period (1997-2003) (18-20,22-38) and 18 in the late time- period (2004-2010) (16,21,27,39-53). The results were analyzed according to the evaluated clinical parameters, namely CAL gain, probing pocket depth reduction, $\mathrm{BG}$ as a percentage and $\mathrm{BG}$ in $\mathrm{mm}$.

\section{Clinical attachment level}

In general, there was a significant overall increase in CAL [overall mean increase in attachment level $=3.048 \mathrm{~mm}, 95 \%$ confidence interval $(95 \% \mathrm{CI})=2.658$ 3.437; $p<0.001]$. This effect was not significantly different for early studies vs. late studies ( $p=0.526)$. The mean increase in CAL for the early studies group was $3.150 \mathrm{~mm} \quad(95 \% \quad$ CI $=2.585-$ $3.715 \mathrm{~mm} ; p<0.001)$ whereas for the late studies group, the mean increase in CAL was $2.937 \mathrm{~mm}(95 \% \mathrm{CI}=2.423-$ $3.450 \mathrm{~mm} ; p<0.001$ ) (Fig. 1).

\section{Probing pocket depth reduction}

Similarly to the gains in CAL, there was a significant overall reduction of probing pocket depth; the overall mean reduction of probing pocket depth was $4.049(95 \%$ CI $=3.659$ 4.440; $p<0.001)$. This effect was not significantly different between early studies and late studies $(p=0.231)$. The mean probing pocket depth reduction for early studies was 4.223 $\mathrm{mm} \quad(95 \% \quad \mathrm{CI}=3.606-4.841 \mathrm{~mm}$; $p<0.001)$, whereas it was $3.845 \mathrm{~mm}$ $(95 \% \quad$ CI $=3.516-4.175 \mathrm{~mm} ; \quad p<$ 0.001) for late studies (Fig. 2).

\section{Bone gain (\%)}

When BG was examined as a percentage, a statistically significant increase of $43.024 \%$ (95\% CI $=30.486-55.563 \%$; $p<0.001)$ was found. However, this was not statistically significantly different between early studies and late studies $(p<0.023)$. Mean BG was $36.212 \%(95 \% \mathrm{CI}=21.030-51.395 \%$; $p<0.001)$ for the early studies and $59.292 \% \quad(95 \% \quad$ CI $=54.109$ $64.474 \%, p<0.001)$ for the late studies. Nonetheless, these results should be regarded with great care because data were available from only two studies in the early studies group (Fig. 3). 
Table 1. Summary of early studies

\begin{tabular}{|c|c|c|c|c|c|c|c|}
\hline Study & Year & $\begin{array}{l}\text { Clinical } \\
\text { attachment } \\
\text { level gain } \\
(\mathrm{mm})\end{array}$ & $\begin{array}{l}\text { Probing } \\
\text { pocket depth } \\
\text { reduction } \\
(\mathrm{mm})\end{array}$ & $\begin{array}{l}\text { Bone gain } \\
(\%)\end{array}$ & $\begin{array}{l}\text { Bone gain } \\
(\mathrm{mm})\end{array}$ & $\begin{array}{l}\text { Defect } \\
\text { morphology }\end{array}$ & $n$ \\
\hline Heijl (18) & 1997 & 2 & 3.2 & 36 & 2.6 & $\begin{array}{l}\text { Predominantly one to two } \\
\text { wall defects each, } n=17\end{array}$ & 34 \\
\hline Zetterstrom (37) & 1997 & 2.9 & 3.7 & 31 & 2.4 & $\begin{array}{l}\text { Intraosseous defects N/A } \\
\text { about wall morphology }\end{array}$ & 45 \\
\hline Sculean (20) & 1999 & 3.2 & 5.7 & & 0.9 & $\begin{array}{l}\text { Teeth scheduled for } \\
\text { extraction N/A }\end{array}$ & 7 \\
\hline Heden (19) & 1999 & 4.6 & 5.2 & 69 & 2.9 & $\begin{array}{l}\text { Intrabony component } \\
\geq 3 \mathrm{~mm} \\
1 \text {-wall }=18 \\
1+2 \text {-wall }=31 \\
\text { 2-wall }=87 \\
\text { 2+3-wall }=7 \\
\text { 3-wall }=2\end{array}$ & 145 \\
\hline Heden (24) & 2000 & 4.2 & 4.7 & 58 & 3.1 & $\begin{array}{l}\text { Intrabony component } \\
\geq 3 \mathrm{~mm} \\
\text { 1-wall }=22 \\
\text { 2-wall }=50\end{array}$ & 72 \\
\hline Okuda (26) & 2000 & 1.72 & 3 & 20.2 & & $\begin{array}{l}\text { Intrabony component } \\
\begin{array}{l}\geq 4 \mathrm{~mm} \\
\text { 1-wall }=5 \\
\text { 2-wall }=5 \\
\text { 3-wall }=8\end{array}\end{array}$ & 18 \\
\hline Parodi (27) & 2000 & 3.43 & 4.9 & & 2.54 & $\begin{array}{l}\text { Angular bony defect } \\
\text { width } \geq 2 \mathrm{~mm} \text { and } \\
\text { depth } \geq 3 \mathrm{~mm}\end{array}$ & 21 \\
\hline Bratthall (22) & 2001 & 2.9 & 3.7 & & 1 & $\begin{array}{l}\text { Intrabony defect width } \\
\geq 2 \mathrm{~mm} \text { and depth } \\
\geq 3 \mathrm{~mm}\end{array}$ & 88 \\
\hline Pietruska (28) & 2001 & 2.9 & 4.24 & & 2.84 & $\begin{array}{l}\text { Defect depth } \geq 3 \mathrm{~mm} \\
\text { Nine, } 2 \text {-wall and three, } \\
\text { 3-wall defects }\end{array}$ & 25 \\
\hline Minabe (25) & 2002 & 2.6 & 3.8 & 35.3 & & $\begin{array}{l}\text { Eleven 3-wall, seven } \\
\text { 2-wall, four 3-wall } \\
\text { defects }\end{array}$ & 17 \\
\hline Windisch (36) & 2002 & 2.67 & 5 & & 1.05 & $\begin{array}{l}1 \text {-wall }=1 \\
2 \text {-wall }=5\end{array}$ & 6 \\
\hline Pontoriero (29) & 1999 & 2.9 & 4.4 & & & $\begin{array}{l}\text { Intrabony component } \\
\geq 3 \mathrm{~mm}\end{array}$ & 10 \\
\hline Sculean (31) & 1999 & 3 & 4.4 & & & $\begin{array}{l}\text { Intrabony defect } \\
\geq 6 \mathrm{~mm}\end{array}$ & 32 \\
\hline Silvestri (32) & 2000 & 4.5 & 4.8 & & & $\begin{array}{l}\text { Predominant 1- or } \\
\text { 2-wall component }\end{array}$ & 10 \\
\hline Sculean (62) & 2001 & 3.4 & 4.1 & & & $\begin{array}{l}1-2 \text {-wall }=4 \\
2 \text {-wall }=6 \\
3 \text {-wall }=4\end{array}$ & 14 \\
\hline Tonetti (34) & 2002 & 3.1 & 3.9 & & & $\begin{array}{l}\text { Intrabony defect } \\
\geq 3 \mathrm{~mm}\end{array}$ & 83 \\
\hline Zuchelli (38) & 2003 & 4.2 & 5.1 & & & $\begin{array}{l}\text { Angular bony defect } \\
\geq 3 \mathrm{~mm}\end{array}$ & 30 \\
\hline Gutierez (23) & 2003 & 1.4 & 2 & & & $\mathrm{~N} / \mathrm{A}$ & 20 \\
\hline Wachtel (35) & 2003 & 3.6 & 3.9 & & & $\begin{array}{l}\text { Intrabony component } \\
\geq 3 \mathrm{~mm} \\
1-, 2-, 3 \text {-wall defects } \\
\text { included }\end{array}$ & 13 \\
\hline Silvestri (33) & 2003 & 4.1 & 5.3 & & & $\begin{array}{l}\text { Intrabony component } \\
\geq 4 \mathrm{~mm} \\
1-, 2-, 3 \text {-wall defects } \\
\text { included }\end{array}$ & 6 \\
\hline
\end{tabular}


Table 1. (Continued)

\begin{tabular}{|c|c|c|c|c|c|c|c|}
\hline Study & Year & $\begin{array}{l}\text { Clinical } \\
\text { attachment } \\
\text { level gain } \\
(\mathrm{mm})\end{array}$ & $\begin{array}{l}\text { Probing } \\
\text { pocket depth } \\
\text { reduction } \\
(\mathrm{mm})\end{array}$ & $\begin{array}{l}\text { Bone gain } \\
(\%)\end{array}$ & $\begin{array}{l}\text { Bone gain } \\
(\mathrm{mm})\end{array}$ & $\begin{array}{l}\text { Defect } \\
\text { morphology }\end{array}$ & $n$ \\
\hline Vandana (53) & 2004 & 3.13 & 4.5 & & 1.4 & $\begin{array}{l}\text { Vertical bone loss on } \\
\text { X-ray }\end{array}$ & 8 \\
\hline Parashis (48) & 2004 & 3.6 & 4.3 & 60 & & $\begin{array}{l}\text { Intrabony component } \\
\geq 4 \mathrm{~mm} \\
2+3 \text {-wall defects }\end{array}$ & 15 \\
\hline Francetti (42) & 2004 & 4.29 & 4.86 & 57.4 & 3.44 & $\begin{array}{l}\text { Intrabony defect } \geq 4 \mathrm{~mm} \\
1-, 2-, 3 \text {-wall defects }\end{array}$ & 12 \\
\hline Sculean $(50)$ & 2004 & 2.9 & 4.3 & & 3.9 & $\begin{array}{l}1-2 \text {-wall }=3 \\
\text { 2-wall }=7 \\
\text { 3-wall }=1\end{array}$ & 10 \\
\hline Sipos (52) & 2005 & 1.28 & 2.86 & & 1.63 & $\begin{array}{l}\text { Radiographic depth } \\
\geq 4 \mathrm{~mm}\end{array}$ & 12 \\
\hline Francetti (43) & 2005 & 3.51 & 4.02 & 55 & 3.18 & Intrabony defect $\geq 4 \mathrm{~mm}$ & 83 \\
\hline Kuru (46) & 2006 & 4.06 & 5.03 & & 2.15 & $\begin{array}{l}\text { Intrbony defect } \geq 4 \mathrm{~mm} \\
1-2 \text {-wall }=4 \\
\text { 2-wall }=7 \\
\text { 3-wall }=9\end{array}$ & 10 \\
\hline Crea (41) & 2008 & 2.5 & 3.5 & 58.8 & 2.4 & Intrabony defect $\geq 4 \mathrm{~mm}$ & 19 \\
\hline Grusovin \& Esposito (44) & 2009 & 3.3 & 3.9 & & 2.5 & $\begin{array}{l}\text { Defect depth } \geq 4 \mathrm{~mm} \\
\text { Defect width } \geq 2 \mathrm{~mm}\end{array}$ & 15 \\
\hline Sanz (16) & 2004 & 3.1 & 3.8 & & & Intbony defect $\geq 3 \mathrm{~mm}$ & 35 \\
\hline Parodi (27) & 2004 & 4.2 & 4.93 & & & $\begin{array}{l}\text { Angular osseous defects } \\
\geq 3 \mathrm{~mm}\end{array}$ & 16 \\
\hline Rosing (49) & 2005 & 2.01 & 4.17 & & & $\begin{array}{l}\text { Defect depth } \geq 3 \mathrm{~mm} \\
\text { Defect width } \geq 2 \mathrm{~mm}\end{array}$ & 14 \\
\hline Sculean (51) & 2005 & 3.9 & 4.5 & & & $\begin{array}{l}\text { Intrabony component } \\
\geq 3 \mathrm{~mm} \text { on X-ray } \\
\text { 1-2-wall }=6 \\
\text { 2-wall }=7 \\
\text { 3-wall }=2\end{array}$ & 15 \\
\hline Bokan (39) & 2006 & 3.7 & 3.9 & & & $\begin{array}{l}\text { Intraosseous component } \\
\geq 3 \mathrm{~mm}\end{array}$ & 19 \\
\hline Chambrone (40) & 2007 & 2.67 & 3.75 & & & $2+3$-wall defects & 13 \\
\hline Leknes (47) & 2009 & 0.5 & 2.5 & & & $\begin{array}{l}\text { Intrabony component } \\
\geq 3 \mathrm{~mm} \\
1-3 \text {-wall defects }\end{array}$ & 13 \\
\hline Sicilliano (21) & 2010 & 2.4 & 2.9 & & & $\begin{array}{l}\text { Intrabony component } \\
\geq 3 \mathrm{~mm} \\
80 \% 1 \text {-wall } \\
2-3 \text {-wall in apical } \\
\text { portion }\end{array}$ & 20 \\
\hline Harrell (45) & 2010 & 3.42 & 3.54 & & & $\begin{array}{l}\text { Sites with X-ray } \\
\text { bone loss N/A }\end{array}$ & 13 \\
\hline Jepsen (63) & 2008 & 1.38 & 2.55 & & 2.07 & $\begin{array}{l}\text { Defect morphology: } \\
\text { 1-wall } \\
\text { 2-wall } \\
\text { Combined 1-2 wall } \\
\text { Circumferential }\end{array}$ & 35 \\
\hline
\end{tabular}

N/A, Not Applicable.

\section{Bone gain (mm)}

The last parameter evaluated was BG expressed in $\mathrm{mm}$. Once again, there was an overall statistically significant BG of $2.35 \mathrm{~mm} \quad(95 \% \quad$ CI $=1.96-2.75 \mathrm{~mm}$; $p<0.001)$. Yet again, this was not sta- tistically significant between early studies and late studies ( $p=0.449)$. Generally, the early studies group had $2.191 \mathrm{~mm}$ $(95 \% \quad \mathrm{CI}=1.530-2.851 \mathrm{~mm} ; \quad p<$ $0.001)$ of BG and the late studies group had $2.49 \mathrm{~mm} \quad(95 \% \quad$ CI $=2.070$ $2.91 \mathrm{~mm} ; p<0.001$ ) of BG. (Fig. 4).

\section{Discussion}

EMD has been a subject of extensive research, ranging from early investigations to prove its efficacy $(18,26,30)$ to late investigations in combination with other regenerative therapy 


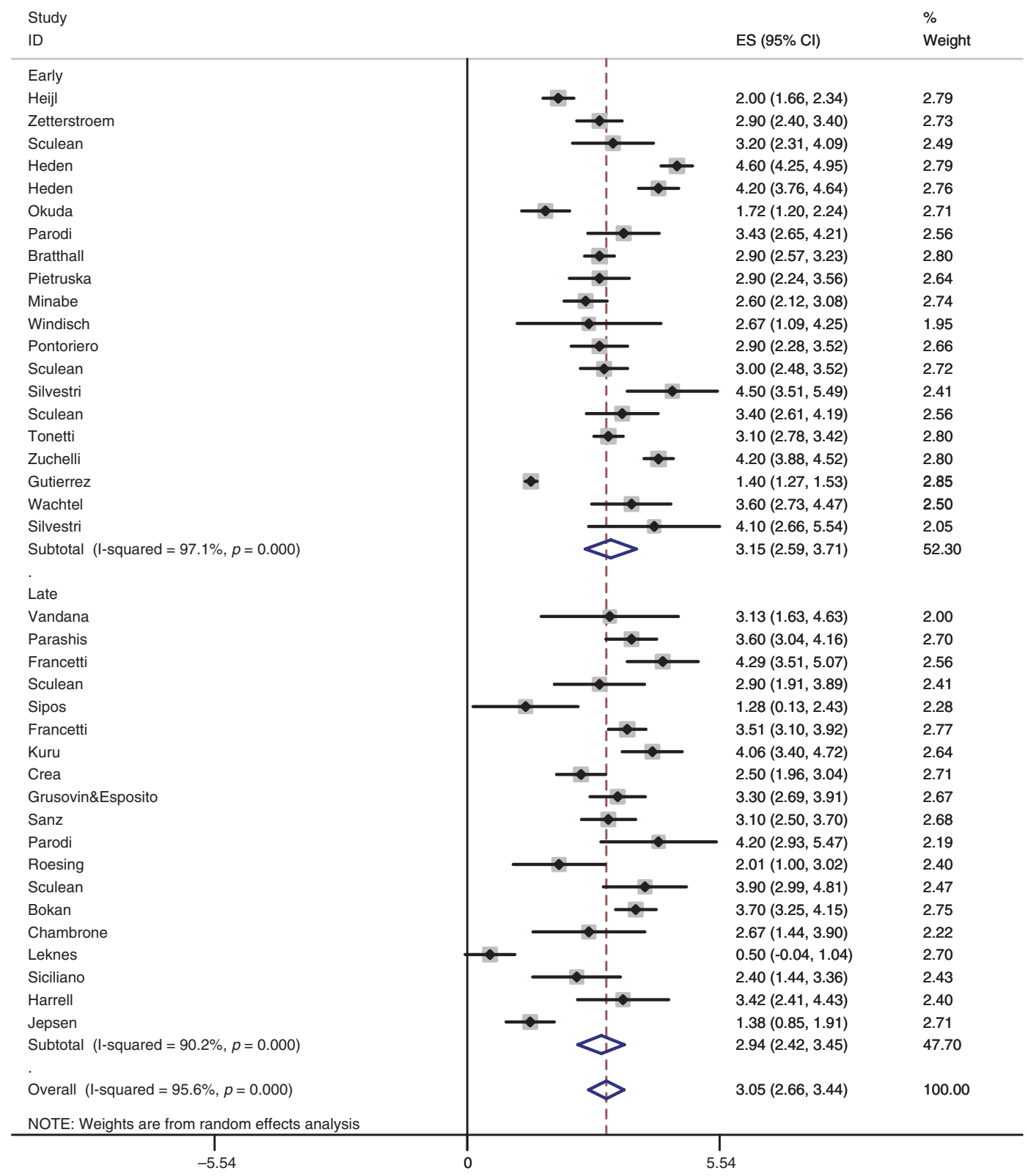

Fig. 1. Random effects analysis of clinical attachment level (CAL) gain.

modalities $(20,25,38,51)$. This metaanalysis found that when EMD was used in combination with flap surgery for the treatment of intrabony defects, a mean CAL gain of $3.04 \mathrm{~mm}$ and a mean probing pocket depth reduction of $4.05 \mathrm{~mm}$ could be obtained. This is in agreement with the findings of Klapidis \& Ruben (54) in their metaanalysis. Esposito et al. $(55,56)$, in a meta-analysis, evaluated CAL gains obtained for EMD treatment compared with open flap debridement, but the effect was reduced by almost half $(1.1 \mathrm{~mm}$ vs. $0.62 \mathrm{~mm})$ when only studies were used that were at low risk for bias. These findings are in contrast to the results reported on CAL gains in our investigation $(3.09 \mathrm{~mm})$ and might be explained by a more stringent exclusion of studies in Esposito's group. Another arm of the meta-analysis of Esposito et al. evaluated the clinical outcomes of EMD vs. GTR and reported no significant difference between the two groups. However, more postoperative complications and recession occurred in the GTR-treated sites. The authors acknowledged the difficulty of the attempted comparisons as a result of the great heterogeneity between the study designs and the outcomes reported $(55,56)$.

Rathe et al. conducted a systematic review evaluating the efficacy of EMD for treating intrabony defects; they concluded that EMD can be used predictably for regeneration of intrabony defects, but found that EMD appears to be more effective in well-contained defects. Furthermore, the amount of bone regeneration was less than achieved with GTR (57). Generally our findings, as far as can be compared, also suggest a significant effectiveness of EMD in 


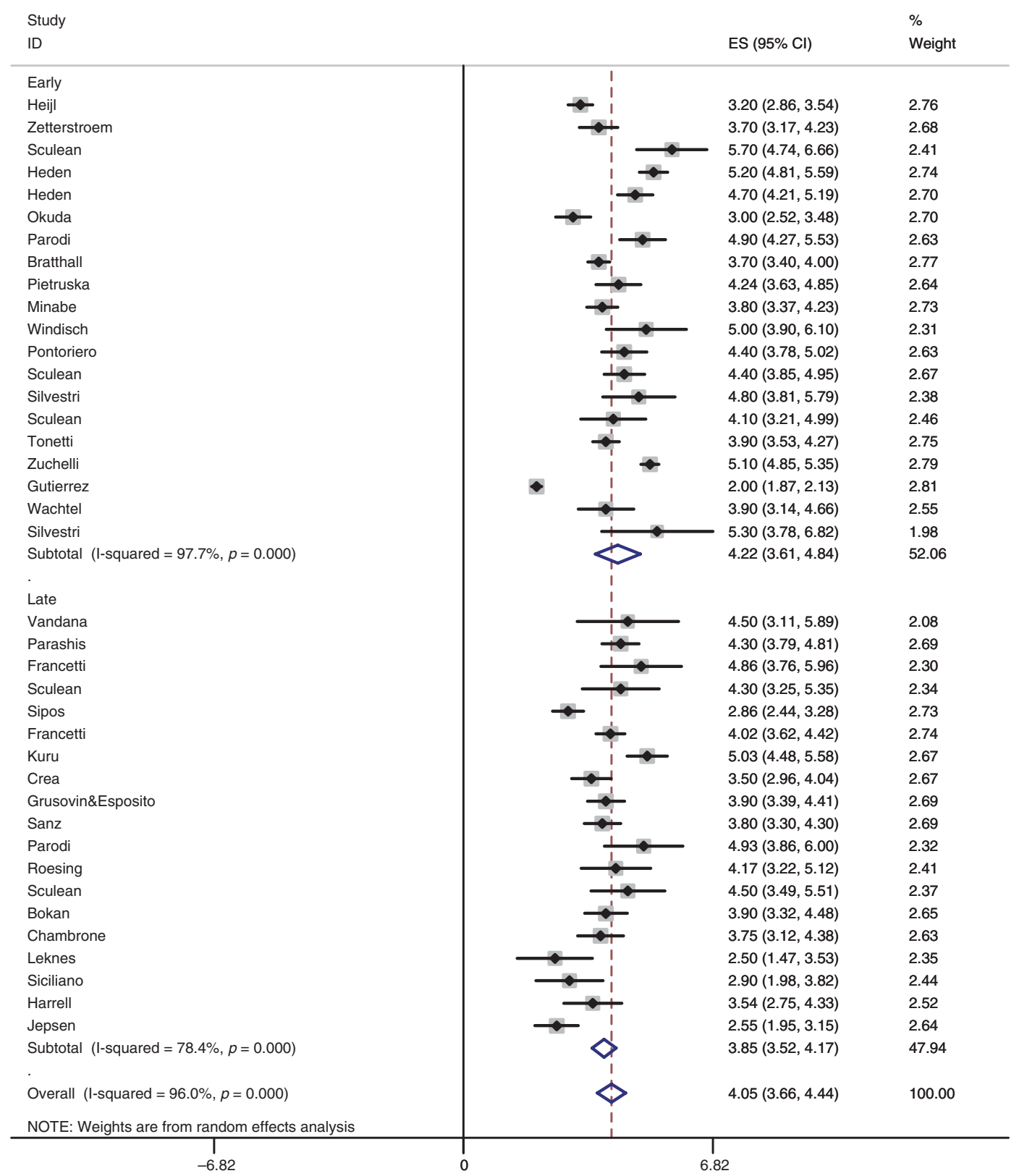

Fig. 2. Random effects analysis of probing pocket depth reduction.

intrabony defects, but the amount of bone regeneration seems to be less pronounced. A comparison between GTR and EMD was not attempted in this meta-analysis and would be valuable for a future comparison.

A benefit associated with the use of EMD can be found when minimally invasive surgical protocols are employed and in esthetic areas $(45,58,59)$. These benefits relate to the ease of application of EMDs. These parameters were not included in the present study design and would be of great interest in future investigations. Siciliano et al. (21) evaluated the performance of EMD vs. GTR in deep, noncontained defects and their results were in favor of the GTR therapy. Clinical application of the above-discussed findings indicates that EMD exhibits potential for regeneration in wellcontained periodontal defects, to enhance wound healing and as an adjunct to root coverage procedures combined with Coronnally Advanced Flap. This might be attributed to the effect of EMD in promoting early soft-tissue healing and subsequent enhancement of wound closure $(17,60,61)$.

In addition, data from this metaanalysis demonstrated a radiographic BG of $43.02 \%$ and $2.35 \mathrm{~mm}$ when EMD plus periodontal flap surgery was used for the treatment of intrabony defects. To the best of our knowledge, no other published metaanalysis has reported BG as a percentage or in $\mathrm{mm}$. 


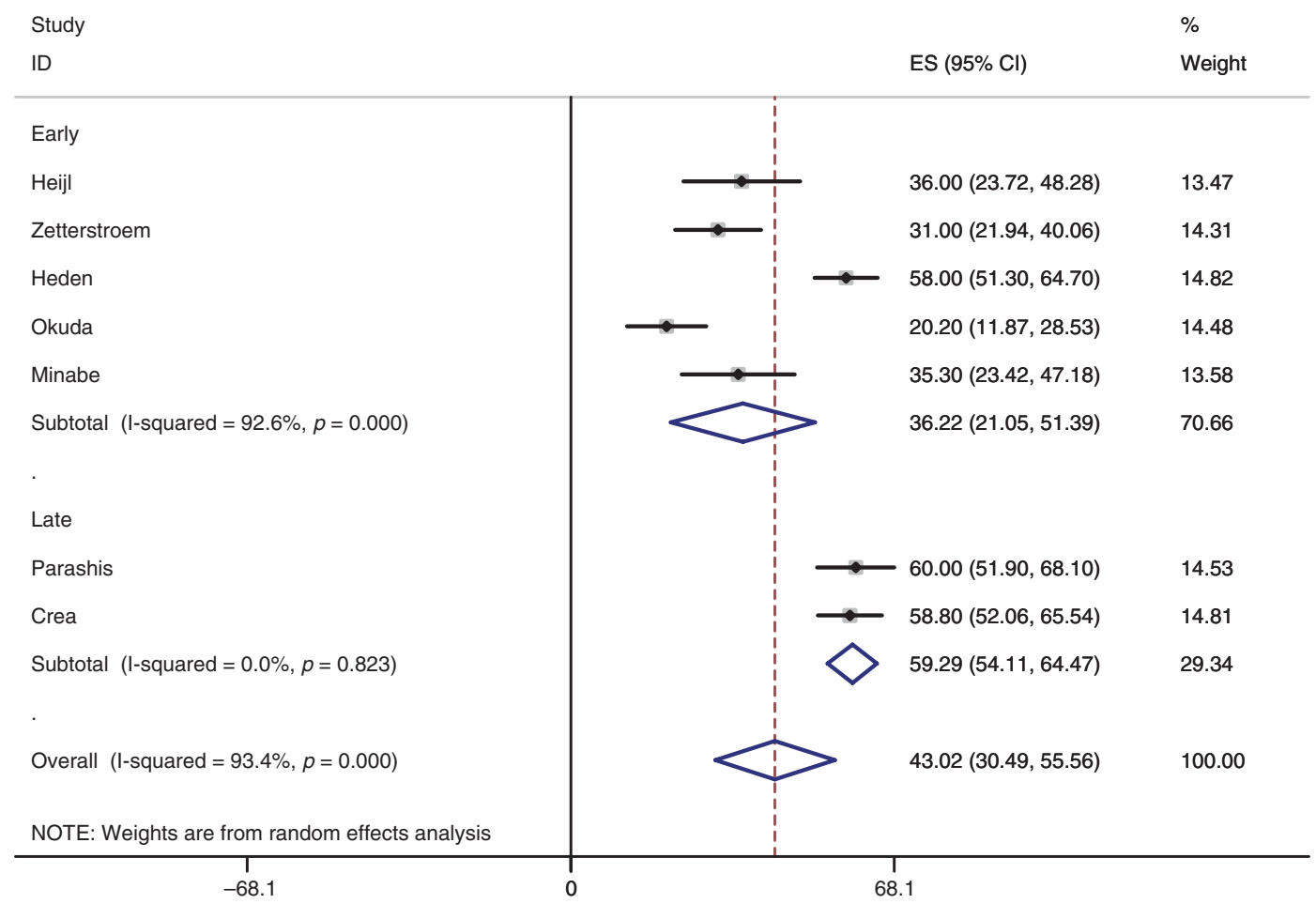

Fig. 3. Random effects analysis of bone gain (BG) expressed as a percentage.

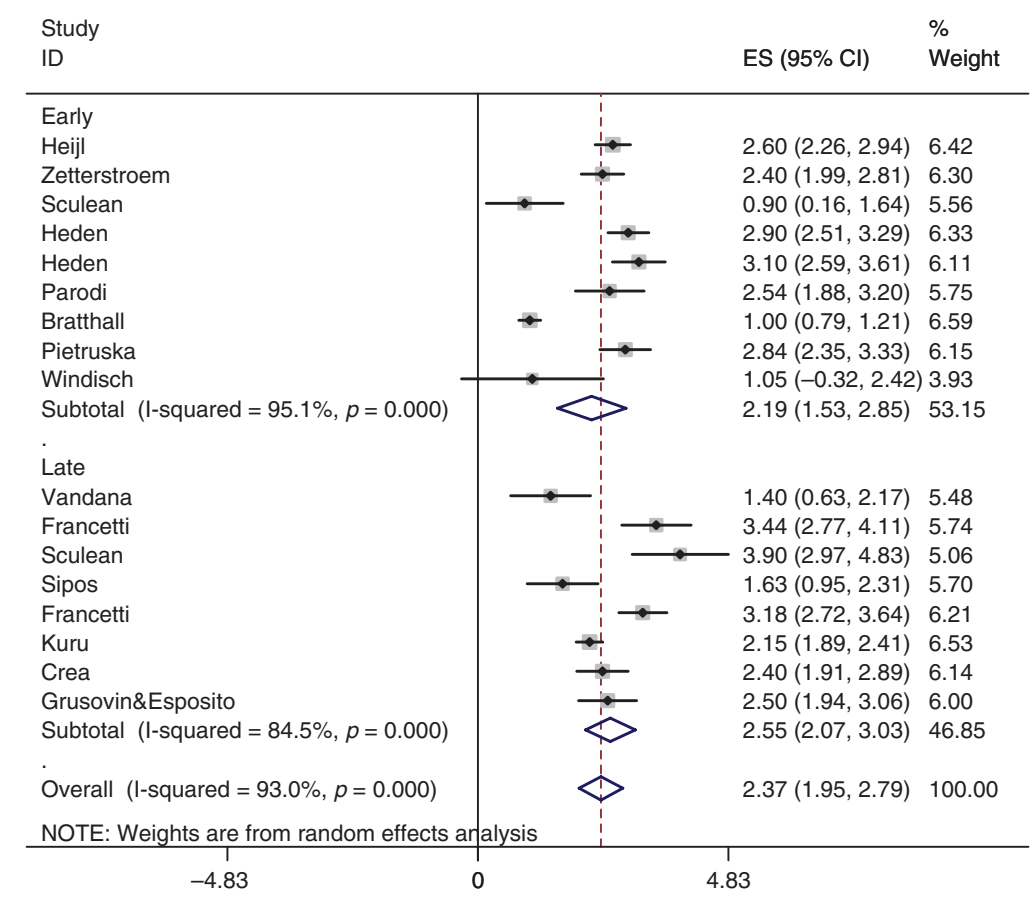

Fig. 4. Random effects analysis of bone gain (BG) expressed in mm.

When these findings were compared with the available data from the $A n$ nals of Periodontology, the efficacy of EMD appeared uncertain $(2,3)$ as a conventional periodontal flap proce- dure can achieve a mean BG of 40 $50 \%$, which is comparable with the results reported for EMD in this metaanalysis. One can assume that there was minimal added benefit of EMD as the percentage of $\mathrm{BG}$ was almost identical to that achieved using the conventional flap surgical procedure. Nonetheless, the benefits of biologic agents, such as EMD, cannot simply be disregarded. Postoperative complications after GTR, for example membrane exposure, have been reported to occur in almost $75 \%$ of sites; however, in the EMD group only $6 \%$ of subjects experienced similar adverse events (16). Lastly, the effect of EMD on $\mathrm{BG}$ has been reported to be less marked than with conventional GTR (57).

To our knowledge, a comparison between early studies (1997-2003) vs. late studies (2004-2010) regarding the treatment of periodontal intrabony defects using EMD has not previously been attempted. Comparison of early studies with late studies identified no statistically significant difference in the efficacy of EMD determined using the following clinical parameters: CAL, probing pocket depth or BG (expressed either as a percentage or in $\mathrm{mm}$ ).

The limitations of this present investigation are the limited sample size, the timelines selected (which could have been further divided into 
additional time intervals) and the sole assessment of EMD. More studies are needed to substantiate or refute the reported results.

\section{Conclusions}

This meta-analysis failed to show any significant differences between the clinical results published in early or later studies regarding the use of EMD to treat periodontal intrabony defects.

\section{Acknowledgements}

This study was partially supported by the University of Michigan Periodontal Graduate Student Research Fund.

\section{Disclaimers}

The authors do not have any financial interests, either directly or indirectly, in the products or information listed in the paper.

\section{References}

1. Laurell L, Gottlow J, Zybutz M, Persson R. Treatment of intrabony defects by different surgical procedures. A literature review. J Periodontol 1998;69:303-313.

2. Murphy KG, Gunsolley JC. Guided tissue regeneration for the treatment of periodontal intrabony and furcation defects. A systematic review. Ann Periodontol 2003;8:266-302.

3. Reynolds MA, Aichelmann-Reidy ME, Branch-Mays GL, Gunsolley JC. The efficacy of bone replacement grafts in the treatment of periodontal osseous defects. A systematic review. Ann Periodontol 2003;8:227-265.

4. Aichelmann-Reidy ME, Reynolds MA. Predictability of clinical outcomes following regenerative therapy in intrabony defects. J Periodontol 2008;79:387393.

5. Cortellini P, Pini Prato G, Tonetti MS. Periodontal regeneration of human infrabony defects. II. Re-entry procedures and bone measures. $J$ Periodontol 1993;64:261-268.

6. Cortellini P, Pini Prato G, Tonetti MS. Periodontal regeneration of human infrabony defects. I. Clinical measures. J Periodontol 1993;64:254-260.

7. Tonetti MS, Pini Prato G, Williams RC, Cortellini P. Periodontal regeneration of human infrabony defects. III. Diagnostic strategies to detect bone gain. J Periodontol 1993;64:269-277.
8. Tonetti MS, Pini-Prato G, Cortellini P. Periodontal regeneration of human intrabony defects. IV. Determinants of healing response. J Periodontol 1993;64: 934-940.

9. Tonetti MS, Pini-Prato G, Cortellini P. Effect of cigarette smoking on periodontal healing following GTR in infrabony defects. A preliminary retrospective study. J Clin Periodontol 1995;22:229-234.

10. Cortellini P, Tonetti MS. Evaluation of the effect of tooth vitality on regenerative outcomes in infrabony defects. $J$ Clin Periodontol 2001;28:672-679.

11. Hammarstrom L, Heijl L, Gestrelius S. Periodontal regeneration in a buccal dehiscence model in monkeys after application of enamel matrix proteins. $J$ Clin Periodontol 1997;24:669-677.

12. Hammarstrom L. Enamel matrix, cementum development and regeneration. J Clin Periodontol 1997;24:658-668.

13. Margolis HC, Beniash E, Fowler CE. Role of macromolecular assembly of enamel matrix proteins in enamel formation. J Dent Res 2006;85:775-793.

14. Bosshardt DD. Biological mediators and periodontal regeneration: a review of enamel matrix proteins at the cellular and molecular levels. $J$ Clin Periodontol 2008;35:87-105.

15. Olitzky I. Antimicrobial properties of a propylene glycol based topical therapeutic agent. J Pharm Sci 1965;54:787-788.

16. Sanz M, Tonetti MS, Zabalegui I et al. Treatment of intrabony defects with enamel matrix proteins or barrier membranes: results from a multicenter practice-based clinical trial. J Periodontol 2004;75:726-733.

17. Spahr A, Haegewald S, Tsoulfidou F et al. Coverage of Miller class I and II recession defects using enamel matrix proteins vs. coronally advanced flap technique: a 2-year report. J Periodontol 2005;76:1871-1880.

18. Heijl L, Heden G, Svardstrom G, Ostgren A. Enamel matrix derivative (EMDOGAIN) in the treatment of intrabony periodontal defects. J Clin Periodontol 1997;24:705-714.

19. Heden G, Wennstrom J, Lindhe J. Periodontal tissue alterations following Emdogain treatment of periodontal sites with angular bone defects. A series of case reports. J Clin Periodontol 1999;26:855860.

20. Sculean A, Donos N, Windisch P et al. Healing of human intrabony defects following treatment with enamel matrix proteins or guided tissue regeneration. J Periodontal Res 1999;34:310-322.

21. Siciliano VI, Andreuccetti G, Siciliano AI, Blasi A, Sculean A, Salvi GE. Clinical outcomes after treatment of noncontained intrabony defects with enamel matrix derivative or guided tissue regeneration: a 12-mo randomized controlled clinical trial. J Periodontol 2011;82: 62-71.

22. Bratthall G, Lindberg P, HavemosePoulsen A et al. Comparison of readyto-use EMDOGAIN-gel and EMDOGAIN in patients with chronic adult periodontitis. J Clin Periodontol 2001;28: 923-929.

23. Gutierrez MA, Mellonig JT, Cochran DL. Evaluation of enamel matrix derivative as an adjunct to non-surgical periodontal therapy. J Clin Periodontol 2003;30:739-745.

24. Heden G. A case report study of 72 consecutive Emdogain-treated intrabony periodontal defects: clinical and radiographic findings after 1 year. Int $J$ Periodontics Restorative Dent 2000;20:127-139.

25. Minabe M, Kodama T, Kogou T et al. A comparative study of combined treatment with a collagen membrane and enamel matrix proteins for the regeneration of intraosseous defects. Int $J$ Periodontics Restorative Dent 2002;22:595-605.

26. Okuda K, Momose M, Miyazaki A et al. Enamel matrix derivative in the treatment of human intrabony osseous defects. J Periodontol 2000;71:1821-1828.

27. Parodi R, Liuzzo G, Patrucco P et al. Use of Emdogain in the treatment of deep intrabony defects: 12-mo clinical results. Histologic and radiographic evaluation. Int $J$ Periodontics Restorative Dent 2000;20:584-595.

28. Pietruska MD. A comparative study on the use of Bio-Oss and enamel matrix derivative (Emdogain) in the treatment of periodontal bone defects. Eur J Oral Sci 2001;109:178-181.

29. Pontoriero R, Wennstrom J, Lindhe J. The use of barrier membranes and enamel matrix proteins in the treatment of angular bone defects. A prospective controlled clinical study. $J$ Clin Periodontol 1999;26:833-840.

30. Sculean A, Blaes A, Arweiler N, Reich E, Donos N, Brecx M. The effect of postsurgical antibiotics on the healing of intrabony defects following treatment with enamel matrix proteins. $J$ Periodontol 2001;72:190-195.

31. Sculean A, Reich E, Chiantella GC, Brecx M. Treatment of intrabony periodontal defects with an enamel matrix protein derivative (Emdogain): a report of 32 cases. Int $J$ Periodontics Restorative Dent 1999; 19:157-163.

32. Silvestri M, Ricci G, Rasperini G, Sartori $\mathrm{S}$, Cattaneo V. Comparison of treatments of infrabony defects with enamel matrix derivative, guided tissue regeneration with a nonresorbable membrane and Widman modified flap. A pilot study. J Clin Periodontol 2000;27:603-610.

33. Silvestri M, Sartori S, Rasperini G, Ricci G, Rota C, Cattaneo V. Comparison of 
infrabony defects treated with enamel matrix derivative vs. guided tissue regeneration with a nonresorbable membrane. $J$ Clin Periodontol 2003;30:386-393.

34. Tonetti MS, Lang NP, Cortellini $\mathrm{P}$ et al. Enamel matrix proteins in the regenerative therapy of deep intrabony defects. $J$ Clin Periodontol 2002;29:317-325.

35. Wachtel H, Schenk G, Bohm S, Weng D, Zuhr O, Hurzeler MB. Microsurgical access flap and enamel matrix derivative for the treatment of periodontal intrabony defects: a controlled clinical study. J Clin Periodontol 2003;30:496-504.

36. Windisch $\mathrm{P}$, Sculean A, Klein F et al. Comparison of clinical, radiographic, and histometric measurements following treatment with guided tissue regeneration or enamel matrix proteins in human periodontal defects. J Periodontol 2002;73: 409-417.

37. Zetterstrom O, Andersson C, Eriksson L et al. Clinical safety of enamel matrix derivative (EMDOGAIN) in the treatment of periodontal defects. J Clin Periodontol 1997;24:697-704.

38. Zucchelli G, Amore C, Montebugnoli L, De Sanctis M. Enamel matrix proteins and bovine porous bone mineral in the treatment of intrabony defects: a comparative controlled clinical trial. J Periodontol 2003;74:1725-1735.

39. Bokan I, Bill JS, Schlagenhauf U. Primary flap closure combined with Emdogain alone or Emdogain and Cerasorb in the treatment of intra-bony defects. $J$ Clin Periodontol 2006;33:885-893.

40. Chambrone D, Pasin IM, Conde MC, Panutti C, Carneiro S, Lima LA. Effect of enamel matrix proteins on the treatment of intrabony defects: a split-mouth randomized controlled trial study. Braz Oral Res 2007;21:241-246.

41. Crea A, Dassatti L, Hoffmann O, Zafiropoulos GG, Deli G. Treatment of intrabony defects using guided tissue regeneration or enamel matrix derivative: a 3-year prospective randomized clinical study. J Periodontol 2008;79:2281-2289.

42. Francetti L, Del Fabbro M, Basso M, Testori T, Weinstein R. Enamel matrix proteins in the treatment of intra-bony defects. A prospective 24-mo clinical trial. J Clin Periodontol 2004;31:52-59.

43. Francetti L, Trombelli L, Lombardo G et al. Evaluation of efficacy of enamel matrix derivative in the treatment of intrabony defects: a 24-mo multicenter study. Int J Periodontics Restorative Dent 2005;25:461-473.
44. Grusovin MG, Esposito M. The efficacy of enamel matrix derivative (Emdogain) for the treatment of deep infrabony periodontal defects: a placebo-controlled randomised clinical trial. Eur J Oral Implantol 2009;2:43-54.

45. Harrel SK, Wilson TG Jr, Nunn ME. Prospective assessment of the use of enamel matrix derivative with minimally invasive surgery: 6-year results. J Periodontol 2010;81:435-441.

46. Kuru B, Yilmaz S, Argin K, Noyan U. Enamel matrix derivative alone or in combination with a bioactive glass in wide intrabony defects. Clin Oral Investig 2006;10:227-234.

47. Leknes KN, Andersen KM, Boe OE, Skavland RJ, Albandar JM. Enamel matrix derivative vs. bioactive ceramic filler in the treatment of intrabony defects: 12-mo results. J Periodontol 2009;80:219-227.

48. Parashis A, Andronikaki-Faldami A, Tsiklakis K. Clinical and radiographic comparison of three regenerative procedures in the treatment of intrabony defects. Int $J$ Periodontics Restorative Dent 2004;24:8190.

49. Rosing CK, Aass AM, Mavropoulos A, Gjermo P. Clinical and radiographic effects of enamel matrix derivative in the treatment of intrabony periodontal defects: a 12-mo longitudinal placebocontrolled clinical trial in adult periodontitis patients. J Periodontol 2005;76: 129-133.

50. Sculean A, Donos N, Schwarz F, Becker J, Brecx M, Arweiler NB. Five-year results following treatment of intrabony defects with enamel matrix proteins and guided tissue regeneration. $J$ Clin Periodontol 2004;31:545-549.

51. Sculean A, Pietruska M, Schwarz F, Willershausen B, Arweiler NB, Auschill TM. Healing of human intrabony defects following regenerative periodontal therapy with an enamel matrix protein derivative alone or combined with a bioactive glass. A controlled clinical study. J Clin Periodontol 2005;32:111-117.

52. Sipos PM, Loos BG, Abbas F, Timmerman MF, van der Velden U. The combined use of enamel matrix proteins and a tetracycline-coated expanded polytetrafluoroethylene barrier membrane in the treatment of intra-osseous defects. $J$ Clin Periodontol 2005;32:765-772.

53. Vandana KL, Shah K, Prakash S. Clinical and radiographic evaluation of Emdogain as a regenerative material in the treatment of interproximal vertical defects in chronic and aggressive periodontitis patients. Int $J$ Periodontics Restorative Dent 2004;24:185-191.

54. Kalpidis CD, Ruben MP. Treatment of intrabony periodontal defects with enamel matrix derivative: a literature review. J Periodontol 2002;73:1360-1376.

55. Esposito M, Grusovin MG, Papanikolaou N, Coulthard P, Worthington HV. Enamel matrix derivative (Emdogain) for periodontal tissue regeneration in intrabony defects. A Cochrane systematic review. Eur J Oral Implantol 2009;2:247-266.

56. Esposito M, Grusovin MG, Coulthard P, Worthington HV. Enamel matrix derivative (Emdogain) for periodontal tissue regeneration in intrabony defects. Cochrane Database Syst Rev. 2009 Oct 7;(4): CD003875.

57. Rathe F, Junker R, Chesnutt BM, Jansen JA. The effect of enamel matrix derivative (Emdogain) on bone formation: a systematic review. Tissue Eng Part B Rev 2009;15:215-224.

58. Cortellini P, Tonetti MS. A minimally invasive surgical technique with an enamel matrix derivative in the regenerative treatment of intra-bony defects: a novel approach to limit morbidity. J Clin Periodontol 2007;34:87-93.

59. Trombelli L, Bottega S, Zucchelli G. Supracrestal soft tissue preservation with enamel matrix proteins in treatment of deep intrabony defects. J Clin Periodontol 2002;29:433-439.

60. Hagewald S, Spahr A, Rompola E, Haller B, Heijl L, Bernimoulin JP. Comparative study of Emdogain and coronally advanced flap technique in the treatment of human gingival recessions. A prospective controlled clinical study. J Clin Periodontol 2002;29:35-41.

61. Cueva MA, Boltchi FE, Hallmon WW, Nunn ME, Rivera-Hidalgo F, Rees T. A comparative study of coronally advanced flaps with and without the addition of enamel matrix derivative in the treatment of marginal tissue recession. $J$ Periodontol 2004;75:949-956.

62. Sculean A, Auschill TM, Donos N, Brecx M, Arweiler NB. Effect of an enamel matrix protein derivative (Emdogain) on ex vivo dental plaque vitality. J Clin Periodontol 2001;28:1074-1078.

63. Jepsen S, Topoll H, Rengers $\mathrm{H}$ et al. Clinical outcomes after treatment of intrabony defects with an EMD/synthetic bone graft or EMD alone: a multicentre randomized-controlled clinical trial. J Clin Periodontol 2008;35:420-428. 